\title{
Presentació. Comportaments demogràfics i integració social de la població estrangera
}

L'interès pels comportaments demogràfics diferencials de la població immigrada o de certes subpoblacions definides per la distància etnocultural d'un grup determinat, ha estat sempre relacionat amb la definició de la integració social.

Va ser als Estats Units, durant la dècada de 1930, quan un cercle d'eugenistes preocupats per la reforma social varen orientar el seu treball no cap a l'anàlisi de la disparitat dels comportaments demogràfics com a signe de divisió social, sinó vers la dissipació d'aquesta com a mostra d'igualació de diversos grups socioeconòmics. Interpretaren la desaparició de les diferències, mesurades com a indicadors sociodemogràfics, com a prova de la mobilitat social ascendent dels menys afavorits. Al principi, centraren l'atenció en la fecunditat i en la diferència racial, però també en la nupcialitat, entesa com una manera de mesurar la distància entre els grups, atès que es considerava l'heterogàmia com l'ascens de classe d'un dels cònjuges que formen la parella $i$, en general, com la millora del col-lectiu al qual pertany aquest individu, i de l'homogeneïtzació de les característiques de les parelles dels diversos grups. L'anàlisi de la distribució espacial, de la concentració i segregació d'un col-lectiu determinat es dirigí també des del principi a la constatació de la dificultat que per a aquest podia implicar el seu aillament en el procés de millora de les condicions de vida. El rendiment escolar fou el darrer fenomen que es va convertir en pedra de toc de la posició relativa d'un grup envers un altre, un cop més, tant per als fills dels immigrats, com per als membres de diverses poblacions definides categorialment a partir de la pertinença racial o etnocultural, amb independència del fet migratori. Es tractava, doncs, de mesurar més els aspectes qualitatius que els quantitatius de la població, mantenint, però, els nivells de democràcia que els règims autoritaris contemporanis negaven en les polítiques eugenistes $\mathrm{i}$ natalistes de l'època (Ramsden, 2003). És a partir d'aquí que podem entendre la primacia que la demografia social, molt influïda per l'eugenèsia reformista, atorgà als estudis basats en la disminució o desaparició de les diferències en els comportaments demogràfics, en la fecunditat, en la nupcialitat, però també en la mobilitat i la distribució territorial i, com ja s'ha esmentat abans, en el rendiment escolar.

Així doncs, des del seu origen, la comparació dels comportaments demogràfics d'individus que pertanyen a diferents poblacions que comparteixen un mateix territori ha assumit com a fons epistemològic «la integració social», tot 
i que aquest concepte no aparegués clarament definit. Intentar establir una genealogia dels estudis sobre els comportaments demogràfics diferencials no és potser la millor manera d'acabar arribant a un consens sobre què s'entén per «integració social». Sí que s'obtindrà, però, una bona radiografia de com han canviat aquelles societats (i disciplines) que intentaven definir canònicament què era la integració. En definitiva, se'ns brinda la possibilitat de comprendre millor unes societats a través del negatiu que representa el discurs sobre la diferència enunciat implícitament en les pràctiques $i$ en les teories que proposen com a «integració social». Si parlem de demografia, implica seguir la traça del que reconeixien com a propi $\mathrm{i}$ com a aliè en el component biològic i social de la reproducció d'una població determinada, i quin era el paper destinat als subgrups categoritzats en aquesta població. Estarem, doncs, ni més ni menys que davant de la formulació del que cada societat ha cregut en un moment determinat que constituïa la base de la seva concepció del govern, entesa com la gestió d'una població en un territori (Foucault, 2006).

D'aquesta manera, la redefinició del que va anomenar-se «assimilació» als estudis clàssics de l'escola de Chicago a la dècada de 1920 (Burgess, 1928), que cristal.litzaria a mitjan anys seixanta en l'obra de Milton Gordon (Gordon, 1964), ha estat producte d'un esforç no només per copsar l'impacte dels nous fluxos migratoris, sinó també el caràcter complex i canviant de la societat receptora, d'una banda, i de l'autonomia del migrant, de l'altra. És així com hem d'interpretar el salt endavant que, inspirant-se en la segmentació dual del mercat de treball (Piore, 1979) va representar la formulació de la hipòtesi d'una integració segmentada (Portes i Zhou, 1993), on progressivament es reconeixerà també el paper de la legislació en la definició del camp de forces que s'estableix en aquest procés desigual (Alba i Nee, 2003). En el darrer estadi, al reconeixement progressiu de la complexitat de les societats receptores, s'hi ha afegit, d'una banda, la sacsejada que, en el terreny teòric, ha representat el transnacionalisme (producte de la globalització) (Castles, 2010) i, de l'altra, la relació dialèctica que s'estableix entre l'immigrat i la societat receptora. És allò que, en la integració social, es defineix com el procés d'adaptació, transgressió o reformulació dels límits que la societat receptora imposa al nouvingut (Massey i Sánchez, 2010). Avançar en l'estudi dels comportaments demogràfics diferencials és avançar en la comprensió de la complexitat de les nostres societats i de les persones que les integren.

En el número 57/3 de Documents D'AnÀLISI GEOGRÀFica que aquí presentem, coordinat per la Dra. Inés Brancós, membre del CED, s’hi recullen parcialment algunes de les intervencions que es produïren en el seminari internacional Demographic behaviours and social integration of immigrants, organitzat pel Grup d'Estudis Demogràfics i de les Migracions (GEDEM), del Centre d'Estudis Demogràfics (CED), que se celebrà al Campus de la Universitat Autònoma de Barcelona, a Bellaterra, entre el 28 i el 30 d'abril de 2010 i que rebé el suport del Ministeri de Ciència i Innovació del Govern espanyol i de l'Agència de Gestió d'Ajuts Universitaris i de Recerca de la Generalitat de Catalunya. Era la intenció del nostre grup de recerca, d'una banda, establir contacte amb estudio- 
sos de renom internacional que estiguessin abordant el mateix tema d'estudi des de perspectives diferents $i$, de l'altra, donar a conèixer les recerques que, en aquell moment, s'estaven duent a terme en el propi Centre d'Estudis Demogràfics sobre la matèria. En la composició final d'aquest monogràfic, s'hi han introduït productes fets de nou expressament per persones que participaren en el seminari, però, en tot cas, se n'ha mantingut l'esperit inicial, és a dir: disposar de participacions que fossin producte de la recerca sobre el comportament de la població estrangera immigrada i dels seus descendents en la mobilitat i la distribució espacial, la formació de la família (tant la fecunditat com la nupcialitat), com també la relació amb la legislació, especialment en referència a la situació de regularitat dels migrats. Hi ha hagut dos temes essencials sobre l'anàlisi dels comportaments demogràfics diferencials que han estat reservats a l'apartat «Estats de la qüestió i documentació». Ens referim a l'educació, d'una banda, i a la inserció en el mercat laboral, de l'altra, perquè s'ha considerat que aquests eren dos àmbits tan importants que excedien el camp estrictament demogràfic i era convenient presentar-ne un estat de la qüestió. Per últim, la selecció de les obres ressenyades al final d'aquesta monografia ha estat marcada tant per la representació de diferents escales geogràfiques, com per la referència a llibres $\mathrm{i}$ a autors que poden considerar-se clàssics o que hi esdevindran.

\section{Referències bibliogràfiques}

Alba, R.D. i Nee, V. (2003). Remaking the American Mainstream: Assimilation and the New Immigration. Cambridge: Harvard University Press.

Burgess, E. (1928). «Residential segregation in American cities». Annals of the American Academy of Political y Social Science, 14, 105-115.

Castles, Stephen i Millers, Mark J. (2009). The Age of Migration: International Population Movements in Modern World. Nova York-Londres: The Guilford Press.

Foucault, M. (2006). Seguridad, territorio, población. Buenos Aires: Fondo de Cultura Económica, 15-44.

Gordon, M. (1964). Assimilation in American Life. Oxford: Oxford University Press.

Massey, D.S. i SÁnCHez, M. (2010). Brokered Boundaries: Creating Immigrant Identity in Anti-Immigrant Times. Nova York: Russel Sage Foundation.

Piore, M. (1979). Birds of Passage: Migrant Labor and Industrial Societies. Nova York: Century University Press.

Portes, A. i Zhou, M. (1993). «The New Second Generation: Segmented Assimilation and Its variants». Annals of the American Academy of Political and Social Science, 530, 76-96.

Ramsen, E. (2003). «Social Demography and Eugenics in the Interwar United States». Population and Development Review, 29 (4), 547-593.

Andreu Domingo $i$ Valls Centre d'Estudis Demogràfics Professor associat al Departament de Geografia de la UAB adomingo@ced.uab.es 